\section{Life in Science}

\section{Armin Dale Kaiser}

Email: adkaiser@stanford.edu

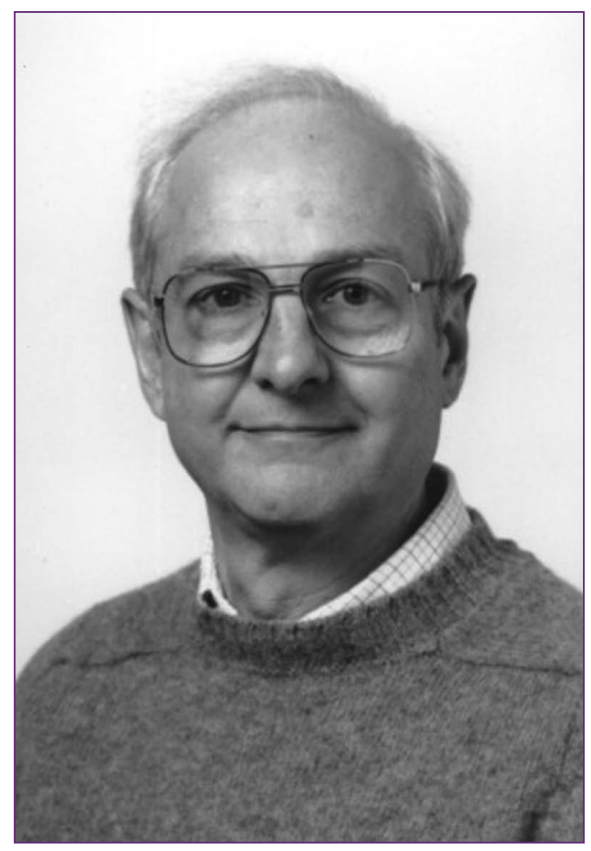

Armin Dale Kaiser, Professor of Biochemistry and of Developmental Biology, Emeritus, Stanford School of Medicine; Stanford, CA USA

My love for experimental biology has grown over the years. My father was a YMCA secretary who ran the Y's summer camp, Camp Wakonda. It was on the Miami and Erie Canal, which at the time was wild and was reminiscent of going back to nature. At camp, Dad taught me to love nature's world, which is why I became an experimental biologist. While I studied at Piqua High School, I worked on Saturdays at Ruble's radio repair shop. Radio sets in those days used vacuum tubes, transformers, resistors and capacitors. It was fun trying to figure out which part was "bad" from the set's symptoms, then trying to fix it. These attempts were my first brush with experimental science.

I attended Purdue University, paid for by the GI Bill, since I had served in the US Army in 1946-47. Freshman year at Purdue provided my first struggle with experimental errors. The freshman engineering course in surveying consisted of tracing a "Dumpy" level circuit around campus from the top of one fire-plug to the next. Somehow, the plug on which we had started the circuit seemed to have changed its elevation significantly 3 days later when we closed the circuit.

I liked all my college teachers, notably my math, physics and chemistry teachers. Humanities classes were also interesting, particularly the discussions of moral and political philosophy. In my sophomore year I realized that I preferred science to engineering, and I shifted from engineering to a science curriculum so that I could study biology, chemistry, physics and mathematics. I applied to several graduate schools in biophysics, which seemed to include all of my interests.

\section{Growing up at Caltech with Bacteriophage Lambda}

I was accepted to a couple of graduate schools but the best offer came from the California Institute of Technology, which not only accepted me but offered to pay my tuition. Biophysics at Caltech was led by Max Delbruck. Advising me on which courses to take, he said, "The committee decided that you have a lot to learn." I was fortunate to study at Caltech because biology was taught as an experimental physical science in the tradition of T.H. Morgan, who had established a Biology Department that put equal emphasis on genetics, plant and animal physiology. Morgan maintained that there was a rational physico-chemical explanation for all biological phenomena. ${ }^{1}$ Delbruck was trying to show that bacteria and bacteriophages had genes whose fundamental properties were similar to those of flies and of corn. His work was part of an exciting venture into biochemical genetics in 1950 going on at Caltech and elsewhere. Beadle, Horowitz and Mitchell were trying to prove one-gene, one-enzyme. Luria and Delbruck had established that phage-resistant mutants were clonally distributed in E. coli cultures. ${ }^{2}$ Avery, MacLeod and McCarty had demonstrated transformation of capsule type in Pneumococcus with DNA extracts that contained very little protein. ${ }^{3}$

Pauling, then chairman of chemistry at Caltech, and working very much in the scientific spirit of Morgan, was making very important contributions to molecular biology by working out the structure of proteins. $\mathrm{He}$ predicted that the left-handed $\alpha$ helix would be found in hair and horn. He also said it was likely to be found in the backbone of some globular proteins like lysozyme, which indeed it is. ${ }^{4}$ Pauling was a great teacher and he became my role model.

At Cold Spring Harbor in the summer of 1951 Delbruck became interested in Visconti's experiments with phage T2. Visconti had been studying the effect of unequal input of the two parents on the recombination frequency observed in a phage cross.

When he made a cross with nine particles of one parent and one of the other, Visconti obtained a striking and unexpected result: the yield contained more recombinant particles than minority parental particles. Delbruck realized that this result could be explained if each phage had several opportunities to recombine during a single growth cycle. This was the origin of the Visconti-Delbruck theory of phage genetics, ${ }^{5}$ which Delbruck worked out in quantitative detail. Delbruck had invited me to accompany him to Cold Spring Harbor that summer, and it was exciting to see the complex body of Visconti's data fall into line as the logical conclusions of a number of clearly stated and plausible assumptions.

Jean Weigle had been Professor of Physics at the University of Geneva where he ran an institute for experimental physics. In 1950, at age 47 and with a distinguished career in physics behind him, he volunteered to become Delbruck's research associate. Weigle investigated the induction of bacteriophage lambda by UV light, and he found many plaque morphology mutants in his irradiated cultures. ${ }^{6}$ When he suggested that I might map those mutants, I eagerly accepted the opportunity. Jean taught me how to do phage research. I certainly could not have had a better teacher. From his experimental physics, Jean knew how to plan experiments, and he was able to spot the flaws in all of my designs. While working on induction of lambda by UV light, he discovered reactivation of UV-killed lambda by UV irradiating the bacteria on which the phage had been plated. A surprising result then, it proved to be one of the first observations of the bacterial SOS response. Jean taught through interpretation of ongoing experiments. He argued endlessly about those interpretations, and he allowed me to join the argument more as a colleague than as a beginning student.

My thesis research consisted of a series of two and three-factor crosses involving 5 mutant alleles of bacteriophage lambda that arose in Weigle's experiments. The alleles were $\mathrm{s}$ (small), later known as red 1 ; $\mathrm{mi}$ (minute), later known as R, or endolysin; $\mathrm{Cl}$, $\mathrm{Cll}$ and clll, later known to specify and to regulate repressor synthesis. The crosses gave an unambiguous linear order of the markers and no interference between crossovers in adjacent intervals.' 
Meanwhile, Jacob and Wollman had mapped another set of genes in lambda. ${ }^{8}$ Francois Jacob accepted me as his first postdoc.

\section{Paris and the Pasteur Institute}

I set out for postdoctoral work in Jacob and Wollman's laboratory with my wife, Mary and our 3-month old daughter. The plan was to test whether the lambda crosses in Paris and in Pasadena involved a single phage chromosome although all the genetic markers were different. From cultures of E. coli, acquired from Paris hospitals, Jacob and Wollman had isolated a series of different temperate bacteriophages that were serologically related to lambda and that could recombine with it, but that had different prophage immunities. ${ }^{9}$ By crossing phage 434, 82 or 21 with lambda marked with $\mathrm{cl}, \mathrm{cll}$ or $\mathrm{clll}$, it was possible to show that lambda differed from 434 only at the cl locus, implying that this locus encoded the repressor and the left and right operator sites. ${ }^{10}$ Other crosses showed that cll and clll controlled the amount of repressor that was made, but not its specificity, which was the function of cl. ${ }^{11}$ Jacob and Wollman were trying to find the relation between the prophage, defined by Lwoff, ${ }^{12}$ and the bacterial chromosome. This was when they discovered the linear transfer of the donor bacterial chromosome to the recipient ${ }^{9}$ with what came to be known as the "spaghetti experiment", after Jacques Monod suggested the image of someone sucking up a single strand of spaghetti through pursed lips.

\section{Washington University Medical School, St. Louis}

Arthur Kornberg offered me a job teaching viral genetics in his medical microbiology course at Washington University Medical School, where he was chairman of the Department of Microbiology. It was the department formerly chaired by J.J. Bronfenbrenner, the first American to have worked with phage ${ }^{13}$ (p142). Bronfenbrenner had hired Al Hershey to help him precipitate phage with antibody. At Washington University, Kornberg was studying the enzymatic synthesis of DNA-which offered an unbelievable opportunity for a geneticist. In 1959, Kornberg invited me to move to Stanford University with him, Berg, Lehman and Hogness, to establish a new Department of Biochemistry at Stanford Medical School. At Stanford a joint project with Kornberg and John Josse on the measurement of nearest neighbor frequencies in $\mathrm{DNA}^{14}$ made it clear to me that an assay for the biological activity of enzymatically replicated DNA was needed. The assay should allow use of mutants to control specificity. Dave Hogness was another member of Kornberg's faculty. Together, Hogness and I tried to develop a way to transform $E$. coli with pure DNA.

\section{Sabbatical at MRC Cambridge}

In 1964, I brought my wife and 2 primary schoolage children to Cambridge for an NSF-sponsored senior postdoctoral fellowship with Hugh Huxley and Aaron Klug. My aim was to learn electron microscopy, negative-staining, and how spherical viruses might be able to assemble themselves. The visit gave me the opportunity to learn the application of Caspar and Klug's theory of quasiequivalence for the symmetry of moderately large, spherical DNA viruses, like bacteriophage $\lambda$ with icosahedral symmetry but more than 60 subunits. John Finch, a patient physicist, who had studied the structure of viruses by X-ray diffraction, taught me how to maintain and focus Huxley's Siemens Electron Microscope. Returning from Cambridge in 1965 to Stanford University, I was able to set up a new EM facility for Arthur Kornberg's Biochemistry laboratory. EM was an important part of Kornberg's demonstration of biologically-active DNA synthesis. I was also able to begin, with my own students and postdocs, to study how bacteriophage $\lambda$ assembled new virus particles. Mutants of $\lambda$ with a genetic defect in head assembly were able to make tails but no heads, and lysates of UV-induced lysogenic bacteria often contained intermediate structures. Even though $\lambda$ head assembly might require a dozen proteins, its molecular basis could be approached because Jean Weigle had discovered that $\lambda$ heads, produced by mutants defective in tail assembly, could spontaneously join to tails in vitro, to form complete and infective $\lambda$ particles. ${ }^{15}$ My lab's efforts began with Sherwood Casjens, a graduate student, and Thomas Hohn, a postdoctoral fellow. They identified protein $\mathrm{E}$ as the major component of the head that accounted for $60 \%$ of the mass of the head, ${ }^{16}$ by joining radioactive heads to nonradioactive tails. Protein D was shown to be the second most abundant component, and it was missing from the small, empty, protein spheres found in lysates and known as "petit $\lambda$ ".16 This suggested an assembly pathway in which protein $E$ formed a hollow shell that expanded with addition of protein D. Using in vitro assembly in cell extracts, proteins $\mathrm{F}$ and $\mathrm{W}$ were shown to add to DNA-filled head particles containing $E$ plus $D$ (as well as other head proteins), rendering them capable of attaching $\lambda$ tails. $^{17}$

The success of Casjens et al. in 1972 with head protein assembly in vitro encouraged Terrie Masuda and me to attempt to package $\lambda$ DNA in cell extracts. Using concentrated soluble extracts of $E$. coli cells ${ }^{18}$ that were lysogenic for $\lambda$, we added pure, genetically marked $\lambda$ DNA and observed the formation of morphologically complete and infective phage particles. ${ }^{19}$ The phage particles that had been assembled were chimeras; they had the proper buoyant density and had a host-range characteristic of the genotype of the lysogen extracted, but the genotype of the particles formed in vitro was that of the DNA that had been added to the extract. ${ }^{19}$ This experiment showed that the cutting and the packaging of DNA inside a head is coupled to the assembly of certain head protein subunits. In vitro packaging of $\lambda$ DNA was significant, not only because it was the first DNA to be packaged in vitro, but also because it allowed each step in the packaging process to be investigated.

\section{Disclosure of Potential Conflicts of Interest}

No potential conflicts of interest were disclosed. 


\section{References}

1. Goodstein JR. 1991. Millikan's school. W.W. Norton, New York, 317pp

2. Luria SE, Delbrück M. Mutations of bacteria from virus sensitivity to virus resistance. Genetics 1943; 28:491-511; PMID:17247100

3. Avery OT, MacLeod CM, McCarty M. Studies on the chemical nature of the substance inducing transformation of pnemococcal types: Induction of transformation by a desoxyribonucleic acid fraction isolated from pneumococcus type III. J Exp Med 1944; 79:137-58; PMID:19871359; http://dx.doi.org/10.1084/ jem.79.2.137

4. Matsumura M, Signor G, Matthews BW. Substantial increase of protein stability by multiple disulphide bonds. Nature 1989; 342:291-3; PMID:2812028; http:// dx.doi.org/10.1038/342291a0

5. Visconti N, Delbrück M. The mechanism of genetic recombination in phage. Genetics 1953; 38:5-33; PMID:17247420

6. Weigle JJ. Induction of mutations in a bacterial virus. Proc Natl Acad Sci U S A 1953; 39:628-36; PMID:16589315; http://dx.doi.org/10.1073/pnas.39.7.628

7. Kaiser AD. A genetic study of the temperate coli- phage. Virology 1955; 1:424-43; PMID:13274744; http:// dx.doi.org/10.1016/0042-6822(55)90036-2

8. Jacob F, Wollman EL. Etude génétique d'un bactériophage tempéré d'Escherichia coli. I. Le système genétique du bactériophage. Ann Inst Pasteur (Paris) 1954; 87:653-73; PMID:14350339

9. Jacob F, Wollman E. 1961. Sexuality and the genetics of bacteria, Academic Press, New York, Ch VII Zygotic Induction and its genetic effects, p 93-100; Ch XIV The phenotypic expression of the genetic material, p255-267 10. Kaiser $A D$, Jacob F. Recombination between related temperate bacteriophages and the genetic control of immunity and prophage localization. Virology 1957; 4:509-21; PMID:13507311; http://dx.doi. org/10.1016/0042-6822(57)90083-1

11. Kaiser AD. Mutations in a temperate bacteriophage affecting its ability to lysogenize Escherichia coli. Virology 1957; 3:42-61; PMID:13409759; http://dx.doi. org/10.1016/0042-6822(57)90022-3

12. Lwoff A. Lysogeny. Bacteriol Rev 1953; 17:269-337; PMID:13105613

13. Fischer P, Lipson C. 1982. Thinking about science. W.W. Norton, New York, 334pp

14. Josse J, Kaiser AD, Kornberg A. Enzymatic synthesis of deoxyribonucleic acid. VIII. Frequencies of nearest neighbor base sequences in deoxyribonucleic acid. J Biol Chem 1961; 236:864-75; PMID:13790780

15. Weigle J. Assembly of phage lambda in vitro. Proc Natl Acad Sci U S A 1966; 55:1462-6; PMID:5227665; http://dx.doi.org/10.1073/pnas.55.6.1462

16. Casjens S, Hohn T, Kaiser AD. Morphological proteins of phage lambda: identification of the major head protein as the product of gene E. Virology 1970; 42:496-507; PMID:4923016; http://dx.doi. org/10.1016/0042-6822(70)90293-X

17. Casjens $S$, Hohn $T$, Kaiser AD. Head assembly steps controlled by genes $\mathrm{F}$ and $\mathrm{W}$ in bacteriophage lambda. J Mol Biol 1972; 64:551-63; PMID:5022189; http://dx.doi. org/10.1016/0022-2836(72)90082-4

18. Wickner W, Brutlag D, Schekman R, Kornberg A. RNA synthesis initiates in vitro conversion of M13 DNA to its replicative form. Proc Natl Acad Sci U S A 1972; 69:965-9; PMID:4554537; http://dx.doi.org/10.1073/pnas.69.4.965

19. Kaiser D, Masuda T. In vitro assembly of bacteriophage Lambda heads. Proc Natl Acad Sci U S A 1973; 70:260-4; PMID:4509659; http://dx.doi.org/10.1073/ pnas.70.1.260 